Vol. 4, $\mathbf{N}^{\circ}$ 2, 2020

Copyright (C) 2020, CINCADER.

ISSN 2522-6908

DOI: https://doi.org/10.32829/nanoj.v4i2.199

\title{
Adsorption of lead and iron present in the waters of the Santa River using titanium dioxide nanoparticles (TiO2) \\ [Adsorción de plomo y hierro presentes en aguas del río Santa utilizando nanopartículas de dióxido de titanio (TiO2)]
}

\author{
Lenin Inquil Ayquipa ${ }^{\mathrm{a}}$, Jhonny Valverde Flores ${ }^{\mathrm{a}, \mathrm{b}}$ \\ aUniversidad Cesar Vallejo, Lima, Peru. \\ ${ }^{\text {b}}$ Facultad de Ciencias, Universidad Nacional Agraria La Molina, Lima, Peru. \\ jvalverde@lamolina.edu.pe
}

Received: 02 November 2020; Accepted: 21 December 2020; Published: 25 December 2020

\section{Resumen}

El objetivo de la investigación fue determinar la adsorción de plomo y hierro en aguas provenientes del Río Santa, jurisdicción de Recuay, Ancash. Luego se realizó la síntesis de nanopartículas de dióxido de titanio (TiO2) por medio de ultrasonido, y por último la adsorción de los iones metálicos presentes en estas aguas mediante las nanopartículas de dióxido de titanio. Los resultados indican que el hierro fue adsorbido en $92.69 \%$ (de $31.86 \mathrm{mg} / \mathrm{L}$ a $2.33 \mathrm{mg} / \mathrm{L}$ ) y el plomo fue adsorbido en $79.58 \%$ (de $2.361 \mathrm{mg} / \mathrm{L}$ a $0.482 \mathrm{mg} / \mathrm{L}$ ) utilizando $600 \mathrm{mg}$ de nanopartículas de dióxido de titanio (TiO2) y un tiempo de tratamiento de 60 minutos de tratamiento.

Palabras clave: Nanopartículas, dióxido de titanio, reducción, plomo, hierro.

\begin{abstract}
The objective of the investigation was to determine adsorption of lead and iron in waters coming from the Santa River, Recuay jurisdiction, Ancash. Then the synthesis of titanium dioxide nanoparticles (TiO2) was carried out by means of ultrasound, and finally the adsorption of the metal ions present in these waters by means of the titanium dioxide nanoparticles. The results indicate that the iron was adsorbed by $92.69 \%$ (from $31.86 \mathrm{mg} / \mathrm{L}$ to $2.33 \mathrm{mg} / \mathrm{L}$ ) and the lead was adsorbed by $79.58 \%$ (from $2.361 \mathrm{mg} / \mathrm{L}$ to $0.482 \mathrm{mg} / \mathrm{L}$ ) using $600 \mathrm{mg}$ of titanium dioxide nanoparticles (TiO2) and a treatment time of 60 minutes of treatment.
\end{abstract}

Keywords: Nanoparticles, Titanium Dioxide, Reduction, Lead, Iron

\section{Introduction}

Water is a fundamental natural resource for the development of life on the planet, since it constitutes an indispensable factor for the development of biological processes (ANA, 2016). Mining is one of the most important sectors for the Peruvian economy. However, as it is a purely extractive activity, it has negative impacts on man and the environment, mainly affecting bodies of water, soil, air, flora and fauna.

In Peru, rivers are polluted by solid waste, sewage, mining environmental liabilities (in Spanish, PAM), industrial and population liabilities; Until 2015, 8,616 PAMs have been identified throughout Peru; The Santa River basin concentrates $10 \%$ of the total with 859 mining environmental liabilities (Ministry of Energy and Mines, 2015). 
The waters of the Santa River that are located at the height of the mining environmental liability Ticapampa, are contaminated by heavy metals; After conducting the water analysis, it was determined that the concentration of heavy metals exceeds the Environmental Quality Standards for water, the main source of contamination is the discharges of mining waste located in the Ticapampa - Recuay section (Graza and Quispe, 2015).

The main metallic ion that pollutes the waters of the Santa River, in the section adjacent to the mining environmental liability Ticapampa is lead $(\mathrm{Pb})$, this metal can accumulate in living organisms in a way that achieves higher concentrations, being this dangerous for the health by presenting a high level of toxicity; manganese $(\mathrm{Mn})$ and iron $(\mathrm{Fe})$ exceed the environmental quality standards for water in the Santa River, the presence of iron in the water causes precipitation and unwanted coloration, while manganese can cause poisoning in mammals at high concentrations (Vera and Rosas, 2017).

Nanotechnology is presented as a technological alternative for the treatment of contaminated water and soils, the use of nanoparticles is applied to eliminate various pollutants from water, such as potentially toxic elements $(\mathrm{Pb} 2+, \mathrm{Cd} 2+, \mathrm{Ag}+, \mathrm{Cu} 2+$ and $\mathrm{Ni} 2+)$ and anions $(\mathrm{As} 3+$ and As5 +), achieving efficient adsorption (Brown, 2013; Martínez et al., 2017).

Below is research related to the study: Metallic lead was removed by $80 \%$ (from 18 to values below $0.05 \mathrm{ppm}$ ) using a filter of bentonite, kaolinite and dolomite (Guerra and Hiyagon, 2012). Using TiO2 nanoparticles under the influence of UV light, it removed $97 \%$ of arsenic in 20 minutes; the TiO2 nanoparticles modified with Fe and under the influence of UV light removed more than $98 \%$ in the first 20 minutes (Oscco, 2014). The adsorption of $100 \%$ of the lead in the effluents from the tannery activity was achieved using cobalt ferrite nanoparticles (Chuquisengo, 2018). Titanium dioxide (TiO2) nanoparticles have improved and even different properties than those of macro size; such as the hardness, elasticity, conductivity, thermal, magnetic and electrical improve when being in nanometric scale; They have a large specific surface area and high surface activity, making them excellent antibacterial agents, sensors, and catalysts. Titanium dioxide nanoparticles have specific properties, which make their use possible in many fields of science and technology; being a stable and non-toxic oxide. Titanium dioxide nanoparticles are also used in photocatalysis, electrochemistry, optics, microelectronics, in the production of colorants, ceramics, cosmetics, gas sensors, inorganic membranes, catalysis cleaning processes, among others (Mosquera et al., 2015).

The present investigation applied nanoparticles of titanium dioxide (TiO2) to achieve the adsorption of metallic ions; with the purpose of decontaminating the waters of the Santa River and thus meeting the environmental quality standards for water required by the Ministry of the Environment.

\section{Materials and Methods}

The research was applied. The research design was experimental. The population was made up of the waters of the Santa River, located in parallel to the mining environmental liability Ticapampa, Recuay province, Ancash region, see figure 1. 


\section{Journal of Nanotechnology}

Vol. 4, $\mathrm{N}^{\circ}$ 2, 2020

Copyright @ 2020, CINCADER.

ISSN 2522-6908

DOI: https://doi.org/10.32829/nanoj.v4i2.199

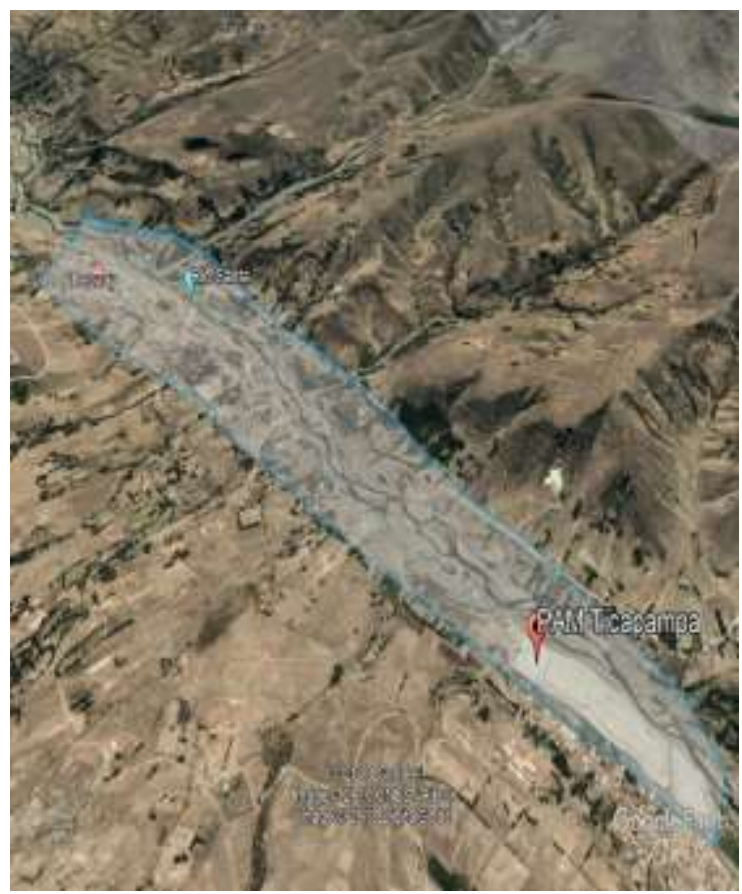

Figure 1. Location of the study area, Ticapampa, Recuay province, Ancash. Source: Google Earth, 2019.

The sample is 15 liters of water contaminated with heavy metals.

The stages of the investigation were:

- Stage 1. Analysis of the initial sample

The first sampling was carried out adjacent to the Recuay municipal stadium in the waters of the Santa River, for subsequent individual analysis. 5 samples were taken; 2 samples for the analysis of Total Metals, 1 sample for the analysis of Oils and Fats, 1 sample for the analysis of BOD and 1 sample for the analysis of Total Suspended Solids. The second sampling point was adjacent to the Ticapampa mining environmental liability, 3 samples of water from the Santa River were taken for the analysis of total metals.

- Stage 2. Synthesis of TiO2 nanoparticles

$6 \mathrm{~g}$ of TiO2 (99\% purity) were dissolved in $80 \mathrm{ml}$ of ethanol $(99.9 \%$ purity). Using ultrasound was applied 5 minutes of the DEGAS process in the solution at a temperature of $50{ }^{\circ} \mathrm{C}$. Sonication was applied at times of $60,90,120,150$ and 180 minutes at an ultrasonic frequency of $40 \mathrm{KHz}$ to reduce the size of the particles. Subsequently, centrifugation was carried out with $30 \mathrm{~mL}$ of distilled water at 5000rpm for 10 minutes. Two phases were obtained, the solid phase was dried at $100^{\circ} \mathrm{C}$ for 30 minutes. Then it was calcined at $500^{\circ} \mathrm{C}$ for 60 minutes obtaining the nanoparticles of titanium dioxide (TiO2).

After carrying out the synthesis of nanoparticles applying different ultrasound times, an average nanoparticle size of 1500,1100 and $500 \mathrm{~nm}$ was obtained in 60,120 and 180 minutes of ultrasound respectively. 
Vol. 4, $\mathrm{N}^{\circ} 2,2020$

Copyright (c) 2020, CINCADER.

ISSN 2522-6908

DOI: https://doi.org/10.32829/nanoj.v4i2.199

- Stage 3. Application of treatment with titanium dioxide nanoparticles.

- Stage 4. Analysis of the final water sample from the Santa River after treatment

\section{Results and discussions}

Results of the analysis of the water samples before and after applying the treatment with titanium dioxide nanoparticles

Table 1. Lead adsorption efficiency $(\mathrm{Pb})$

\begin{tabular}{cccccc}
\hline $\begin{array}{c}\text { Analyzed } \\
\text { metal }\end{array}$ & $\begin{array}{c}\text { Initial } \\
\text { concentration } \\
(\mathbf{m g} / \mathbf{L})\end{array}$ & $\begin{array}{c}\text { Final } \\
\text { concentration } \\
(\mathbf{m g} / \mathbf{L})\end{array}$ & $\begin{array}{c}\text { Nanoparticles } \\
\text { weight }(\mathbf{m g})\end{array}$ & $\begin{array}{c}\text { Treatment } \\
\text { time (min) }\end{array}$ & $\begin{array}{c}\text { Adsorption } \\
\text { percentage } \\
(\%)\end{array}$ \\
\hline \multirow{3}{*}{ Lead $(\mathrm{Pb})$} & 2.361 & 0.726 & 200 & 20 & 69.25 \\
& & 0.666 & 200 & 40 & 71.79 \\
& & 0.581 & 200 & 60 & 75.39 \\
\hline \multirow{3}{*}{ Lead $(\mathrm{Pb})$} & 2.361 & 0.687 & 400 & 20 & 70.90 \\
& & 0.596 & 400 & 40 & 74.75 \\
& & 0.592 & 400 & 60 & 74.93 \\
\hline \multirow{2}{*}{ Lead $(\mathrm{Pb})$} & 2.361 & 0.552 & 600 & 20 & 76.62 \\
& & 0.527 & 600 & 40 & 77.68 \\
& & 0.482 & 600 & 60 & 79.58 \\
\hline
\end{tabular}

Using $200 \mathrm{mg}$ of TiO2 nanoparticles, an efficiency of $69.25 \%, 71.79 \%$ and $75.39 \%$ was achieved in the adsorption of lead in 20, 40 and 60 minutes of treatment respectively.

Using $400 \mathrm{mg}$ of TiO2 nanoparticles, an efficiency of $70.90 \%, 74.75 \%$ and $74.93 \%$ was achieved in the adsorption of lead in 20, 40 and 60 minutes of treatment respectively.

Using $600 \mathrm{mg}$ of TiO2 nanoparticles, an efficiency of $76.62 \%, 77.68 \%$ and $79.58 \%$ was achieved in lead adsorption in 20, 40 and 60 minutes of treatment respectively.

Table 2. Iron (Fe) adsorption efficiency

\begin{tabular}{|c|c|c|c|c|c|}
\hline $\begin{array}{c}\text { Analyzed } \\
\text { metal }\end{array}$ & $\begin{array}{c}\text { Initial } \\
\text { concentration } \\
(\mathrm{mg} / \mathrm{L})\end{array}$ & $\begin{array}{c}\text { Final } \\
\text { concentration } \\
(\mathrm{mg} / \mathrm{L})\end{array}$ & $\begin{array}{c}\text { Nanoparticles } \\
\text { weight (mg) }\end{array}$ & $\begin{array}{l}\text { Treatment } \\
\text { time (min) }\end{array}$ & $\begin{array}{c}\text { Adsorption } \\
\text { percentage } \\
\text { (\%) }\end{array}$ \\
\hline \multirow{3}{*}{ Iron $(\mathrm{Fe})$} & \multirow{3}{*}{31.86} & 4.43 & 200 & 20 & 86.09 \\
\hline & & 4.09 & 200 & 40 & 87.16 \\
\hline & & 3.99 & 200 & 60 & 87.48 \\
\hline \multirow{3}{*}{ Iron $(\mathrm{Fe})$} & \multirow{3}{*}{31.86} & 3.89 & 400 & 20 & 87.79 \\
\hline & & 3.64 & 400 & 40 & 88.58 \\
\hline & & 3.54 & 400 & 60 & 88.89 \\
\hline \multirow{3}{*}{ Iron $(\mathrm{Fe})$} & \multirow{3}{*}{31.86} & 3.25 & 600 & 20 & 89.80 \\
\hline & & 2.57 & 600 & 40 & 91.93 \\
\hline & & 2.33 & 600 & 60 & 92.69 \\
\hline
\end{tabular}

Using $200 \mathrm{mg}$ of TiO2 nanoparticles, an efficiency of $86.09 \%, 87.16 \%$ and $87.48 \%$ was achieved in the adsorption of iron in 20, 40 and 60 minutes of treatment respectively.

Using $400 \mathrm{mg}$ of $\mathrm{TiO} 2$ nanoparticles, an efficiency of $87.79 \%, 88.58 \%$ and $88.89 \%$ in iron adsorption was achieved in 20, 40 and 60 minutes of treatment respectively. 
Vol. 4, $\mathbf{N}^{\circ}$ 2, 2020

Using $600 \mathrm{mg}$ of TiO2 nanoparticles, an efficiency of $89.80 \%, 91.93 \%$ and $92.69 \%$ was achieved in iron adsorption in 20, 40 and 60 minutes of treatment respectively.

\section{Conclusions}

- Lead and iron were adsorbed in waters coming from the Santa River by applying titanium dioxide nanoparticles. It was established that the necessary concentration of titanium dioxide nanoparticles for the adsorption of lead and iron in waters coming from the Santa River was $200 \mathrm{mg}$, $400 \mathrm{mg}$ and $600 \mathrm{mg}$; the latter being the one that obtained the best adsorption results. It was determined that the treatment time for the adsorption of lead and iron in waters coming from the Santa River was 20, 40 and 60 minutes; the latter being the one that obtained the best adsorption results. Up to $1,879 \mathrm{mg} / \mathrm{L}$ lead was adsorbed, which is equivalent to a maximum adsorption efficiency of $79.58 \%$. It was possible to adsorb up to $29.53 \mathrm{mg} / \mathrm{L}$ of iron, which is equivalent to a maximum adsorption efficiency of $92.69 \%$

\section{References}

ANA. 2016. Dirección de Gestión de Calidad de los Recursos Hídricos. Protocolo nacional para el monitoreo de la calidad de los recursos hídricos superficiales.

Brown, Kenneth. 2013, Adsorption. Salem Press Encyclopedia of Science.

Chuquisengo Picon, Llojan. 2018. Adsorción de plomo (Pb), cadmio $(\mathrm{Cd})$ y cromo $(\mathrm{Cr})$ en aguas mediante nanopartículas estabilizadas de ferrita de cobalto (CoFe2O4). Tesis (Grado de Magister en Scientiae en Ciencias Ambientales). Lima: Universidad Nacional Agraria la Molina.

Graza Franklin y Quispe Ronald. 2015. Determinación de Pb, Cd, As en aguas del río Santa en el pasivo minero ambiental de Recuay, Ticapampa; Recuay - Ancash. tesis. Lima: Universidad Mayor de San Marcos,

cybertesis.unmsm.edu.pe/bitstream/handle/cybertesis/4205/Quispe_pr.pdf?sequence=1\&isAllo wed $=y$

Guerra Alfredo y Hiyagon, Genevie. 2012. Tratamiento de agua para la remoción de plomo aplicando nanotecnología. Tesis (Título profesional de Ingeniero Sanitario). Lima: Universidad Nacional de Ingeniería,

Huamán Aguirre, Arnold. 2015. Producción de nanopartículas de dióxido de titanio por molienda húmeda: caracterización y aplicación a celdas solares sensibilizadas con colorante. Tesis. Lima: Universidad Nacional de Ingeniería.

Martinez Gómez, M. A., Carrillo González, R., González Chávez, M. A. 2017. Aplicaciones y desafíos de la nanotecnología en el control y mitigación de la contaminación. Agroproductividad, 10(4), 73-79. ISSN: 0188-7394

MINISTERIO de Energía y Minas, 2015. Inventario de Pasivos Ambientales Mineros.

Mosquera, Rosas, Debut. 2015, Síntesis y caracterización de nanopartículas de dióxido de titanio obtenidas por el método de sol-gel. Revista Politécnica, vol. 36, no 3, p.7.

Oscco Choque, Fernando. 2014. Estudio físico-químico de nanopartículas de TiO2, TiO2 - Fe y TiO2 impregnadas en carbón activado para la remoción de arsénico. Tesis. Lima: Universidad Nacional de Ingeniería, cybertesis.uni.edu.pe/bitstream/uni/4200/1/oscco_cf.pdf

Vera Deysi, Rosas Luz. 2017. Modelar la contaminación del agua de la represa de aguada blanca, por hierro y manganeso, entre la temporada de lluvias del estiaje, para proporcionar agua de calidad a la población de Arequipa. Tesis. Arequipa: Universidad Nacional de San Agustín de Arequipa, repositorio.unsa.edu.pe/handle/UNSA/6088 